\title{
The Genesis of Thorium-Rich Monazite Placer Deposits in Sri Lanka
}

\author{
M. S. RUPASINGHE \\ Institut für Edelsteinforschung, Saarstrasse 21, D-6500 Mainz, West Germany \\ AND
}

W. GOCHT

Forschungsinstitut für Technische Wirtschaftlische Zusammenarbeit der Rein-Westf. Technischen Hochschule Aachen, Henricistrasse 50, 5100 Aachen, West Germany

AND

C. B. DISSANAYAKE

Department of Geology, University of Peradeniya, Peradeniya, Sri Lanka

(Date of receipt: 04 April 1983)

(Date of acceptance: 23 June 1983)

\begin{abstract}
The monazite placers of Sri Lanka are among the world's most thorium rich sediments. This study of the stream sediments and rocks from an area in the southwest of Sri Lanka shows that the highly metamorphosed aluminous schists and gneisses and also granitoid rocks of the Highland and South-west Groups of the Precambrian of Sri Lanka are the probable source rocks for the thorium-rich monazite. The magmatic fluids known to have pervaded the aluminous sediments during the intense folding and metamorphism under granulite facies conditions are considered to have been thorium rich. The P-T conditions of metamorphism proved to be ideal for the formation of a variety of gem minerals including gem monazite and other associated heavy minerals.
\end{abstract}

\section{Introduction}

Gems, and to a lesser extent gold, are increasingly being found in the sediments of streams draining the central Highland Group of rocks in Sri Lanka. Due to the recent large-scale gem mineral discoveries the study of gemstones of Sri Lanka has been the subject of several recent studies. ${ }^{4},{ }^{11},{ }^{13},{ }^{17}$ It has also been found that in some sediments gems are closely associated with gold. ${ }^{5}$ Whereas much emphasis has been placed on gemstones as a useful export commodity, the thorium bearing monazite stream sediments of Sri Lanka have not been given the same consideration and indeed their potential is great as shown by the recent work of the Geological Survey of Sri Lanka.

This paper deals with the genesis of thorium-rich heavy minerals, particularly monazite, in the stream sediments of the Bentota River, in the southwest of Sri Lanka. This stream drains an area containing abundant gemstones and some alluvial gold. The area under consideration is a mineralized terrain and large alluvial or 'beach' deposits of monazite are found at the mouth of the Bentota River. Uranium and thorium are known to be found in relatively high concentrations in this area. Using 
the abundance of the heavy mineral suites supplemented by petrographic studies of rock thin sections, an attempt has been made to trace: the source rocks of the thoriumrich monazite.

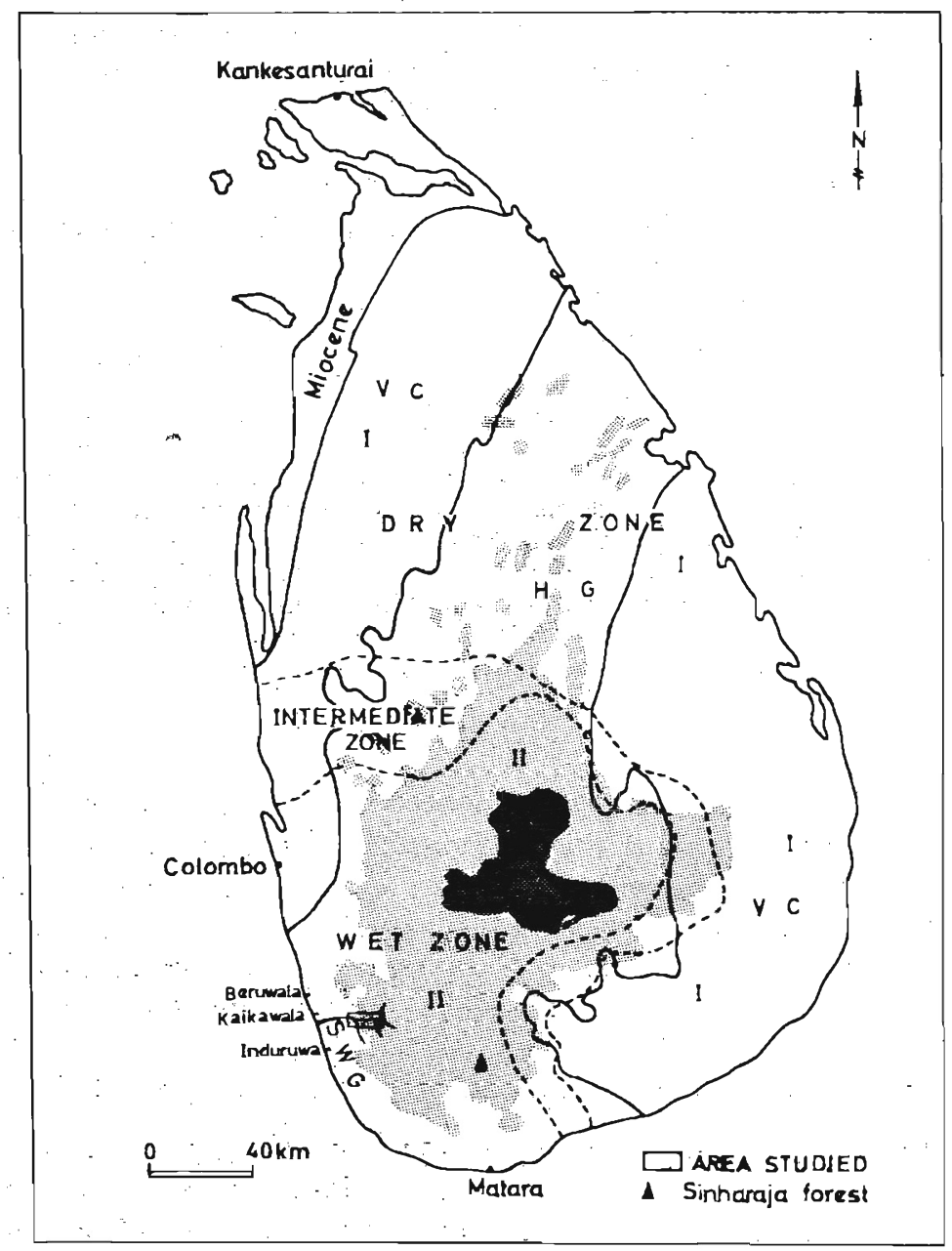

Figure 1 - Map showing the area stadied. VC-Vijayan Complex; HG Highlarid Group; SWG - Southwest Group. 1 - Lowlands Il Uplands III - Highland s. 


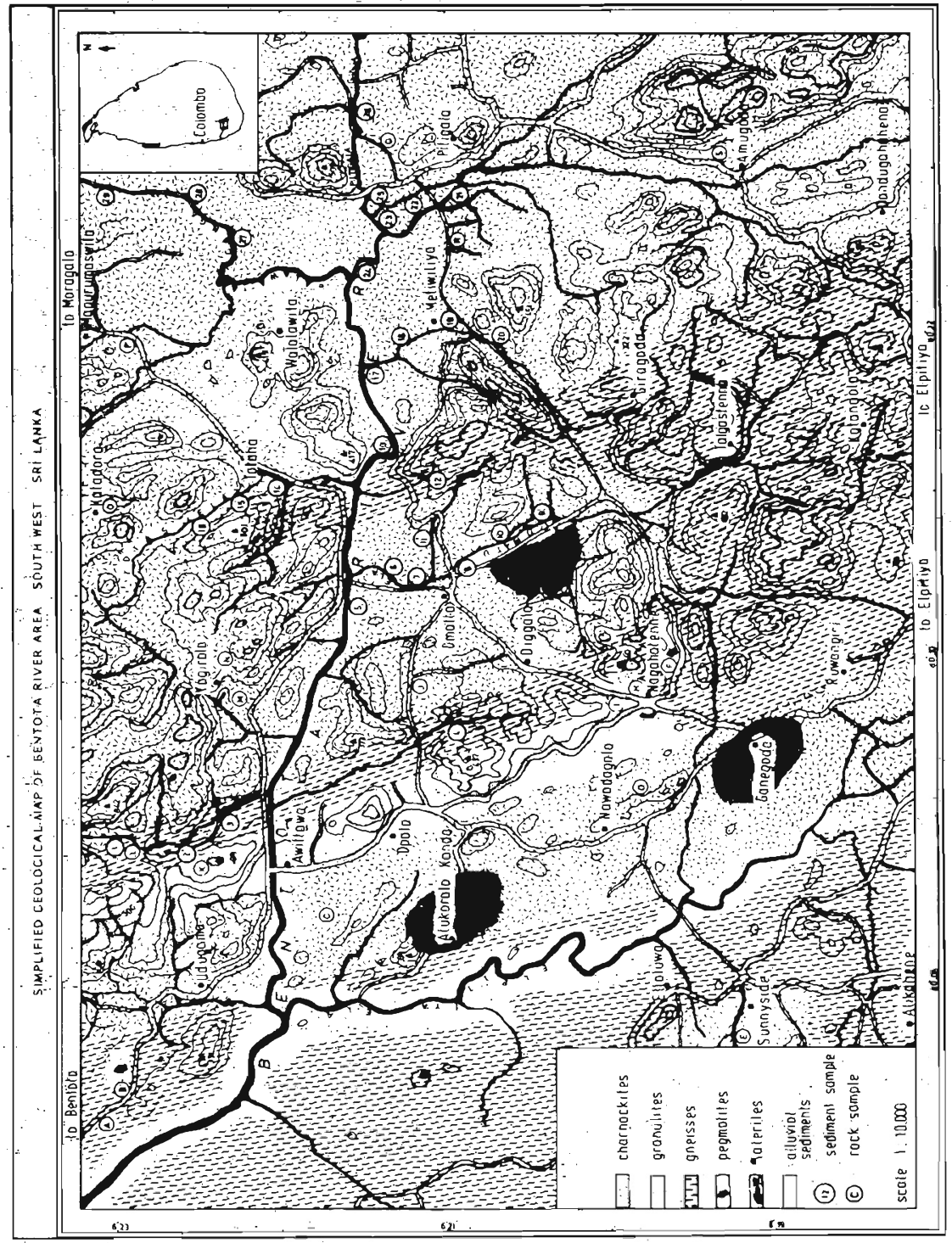

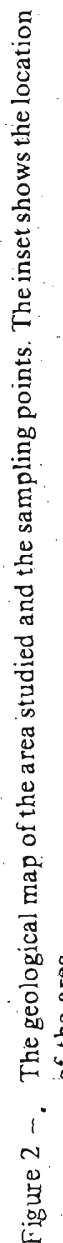




\section{General geology of the area}

Figure 1 illustrates the location of the area studied with respect to the general geology and physiography of Sri Lanka. The area lies within the Southwest Group of rocks comprising mainly of wollastonite bearing calciphyres, cordierite gneisses with sillimanite, corundum and sapphirine as accessory minerals. Migmatites, charnockitic gneisses and granitoid rocks are also common in the Southwest Group.

The major part of the area is drained by the Bentota river and its complex system of tributaries. The rocks are predominantly plutonic and of Precambrian age, superficial Quaternary deposits being confined to the valleys carved by the Bentota river. The Precambrian rocks comprise mainly of charnockites and granitic gneisses with subordinate metasedimentary bands. ${ }^{3,16}$. Among the metasediments are calcgranulites and gneisses, quartzites and quartz schists, quartzfeldspar (garnet) granulites and gneisses, garnet-sillimanite (cordierite) granulites and biotite-garnetgraphite gneisses. As noted by Cooray ${ }_{3}^{3}$ small granitic bodies, pegmatites and dolerites intrude into the crystalline rocks, the pegmatites being both charnockitic and granitic in character. It has been found that some of the granitic pegmatites carry thorium and uranium bearing minerals such as monazite and thorianite.

Monazite occurs as a seasonal beach sand deposit at Kaikawala and Beruwala (Figure 1) where it is associated with ilmenite, garnet, rutile and zircon. Even though monazite is mined on a small scale at Kaikawala beach, very little attention has been paid to the monazite bearing stream sediments as studied in this paper.

\section{Materials and methods}

Figure 2 illustrates the sampling locations. A total of 31 sediment samples and 19 rock samples were obtained. The sediments were taken from tributaries very close to the main Bentota river since a very dense mangrove vegetation prevented the accessibility. Close to the main river the distance between sampling points was between $300-400 \mathrm{~m}$ and further away from the main river the distance between the sampling points increased as shown in Figure 2 . The sediment samples were obtained by making a hole $1 \mathrm{~m}^{2}$ in the sand and cutting a thin groove so as to obtain composite samples from different stratigraphic horizons. Approximately $5 \mathrm{~kg}$ of sediments from each sampling point were sent to the laboratory for analysis.

\section{Results and discussion}

The screened fractions of the total sediments and the percentage of heavy minerals in the various fractions are illustrated graphically in Figure 3. Figures $4 a-4 d$ illustrate the heavy mineral contents of the samples analysed, the major heavy minerais observed being ilmenite, garnet, zircon and monazite. Ilmenite in general is found in the highest concentration and ranges from $30-71 \%$ of the total sediment. Based on these studies the heavy mineral distribution in the streams studied can be shown as in Figure 5 . The 
highest heavy mineral concentrations are found in the regions of Gonagala and Omatu Ela and also Pitigala Ganga (Figure 2), all the heavy minerals studied showing a similar pattern of distribution.

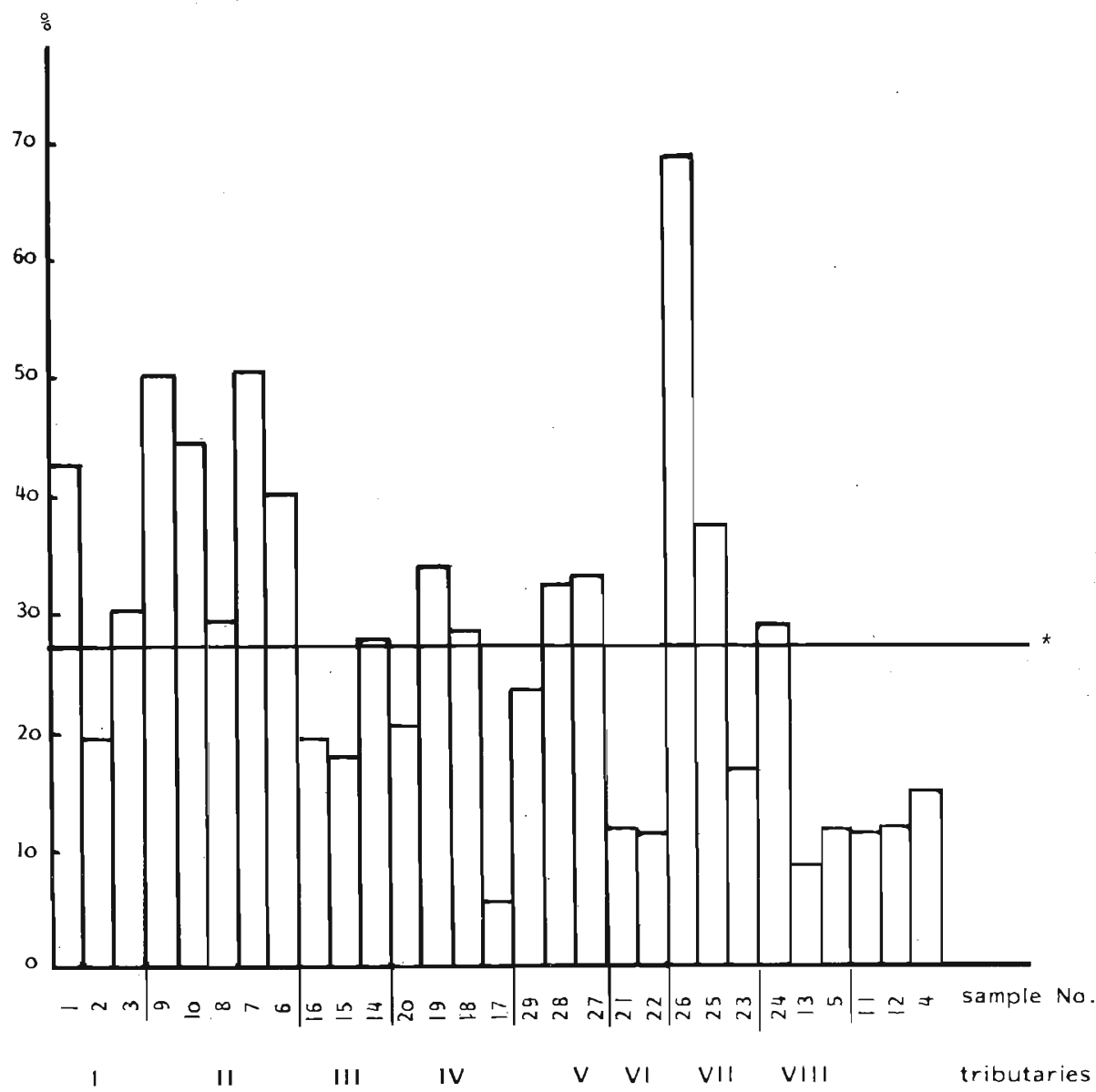

Figure 3 - Histogram showing the total wt $\%$ of heavy minerals in tributaries.

* Average total heavy mineral content of the area. The sample numbers refer to those as given in fig. 2. The tributaries from which the samples were collected are as follows. I Gonagala Ela, II - Omatu Ela, III - Totas Ela, IV - Metiwiliya Ela, V and VI - Palawatta Ganga VII - Pitigala Ganga VIII - Bentota River. 
Monazite in particular was well known as forming placer deposits in Sri Lanka as far back as $1903 .^{2,6} \mathrm{~A}$ further point of interest was the fact that this monazite contained an average of $10 \% \mathrm{ThO}_{2}$, which was higher than the average of commercial monazite from sources elsewhere in the world. ${ }^{15}$ Overstreet $^{15}$ interpreted this high average for $\mathrm{ThO}_{2}$ in the monazite to reflect the uniformly plutonic character of the source rocks in Sri Lanka and concluded that the monazite crystallized in the gneisses and schists when they were metamorphosed. This interpretation differed from the concept that monazite in the gneisses were relict detrital grains. ${ }^{1}$ Even though not many localities had been mentioned in the literature as examples of monazite in the crystalline rocks in Sri Lanka, the similarity between the monazite in the granulite and
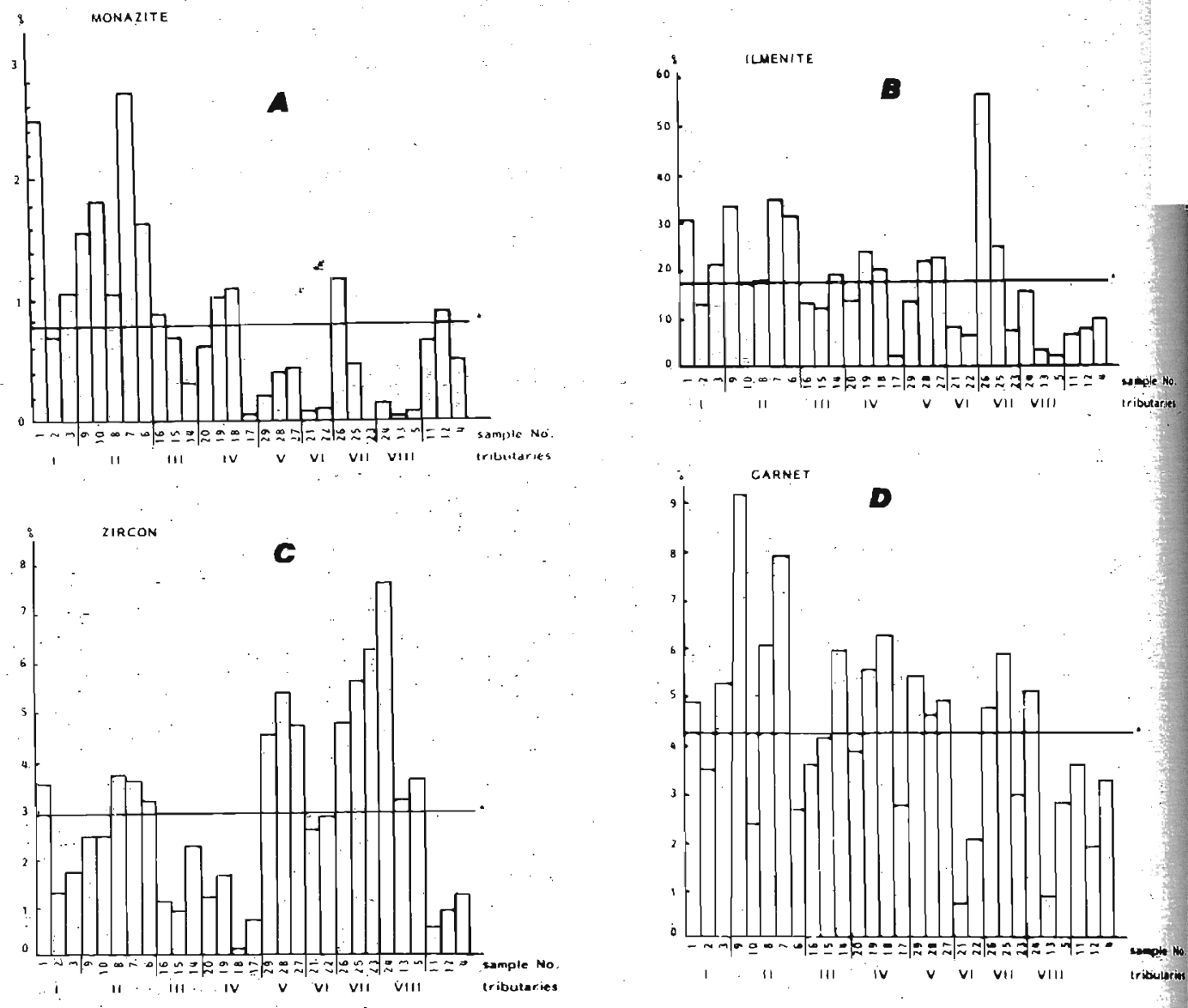

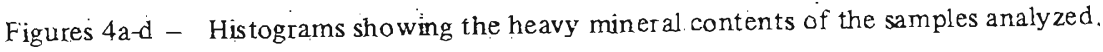




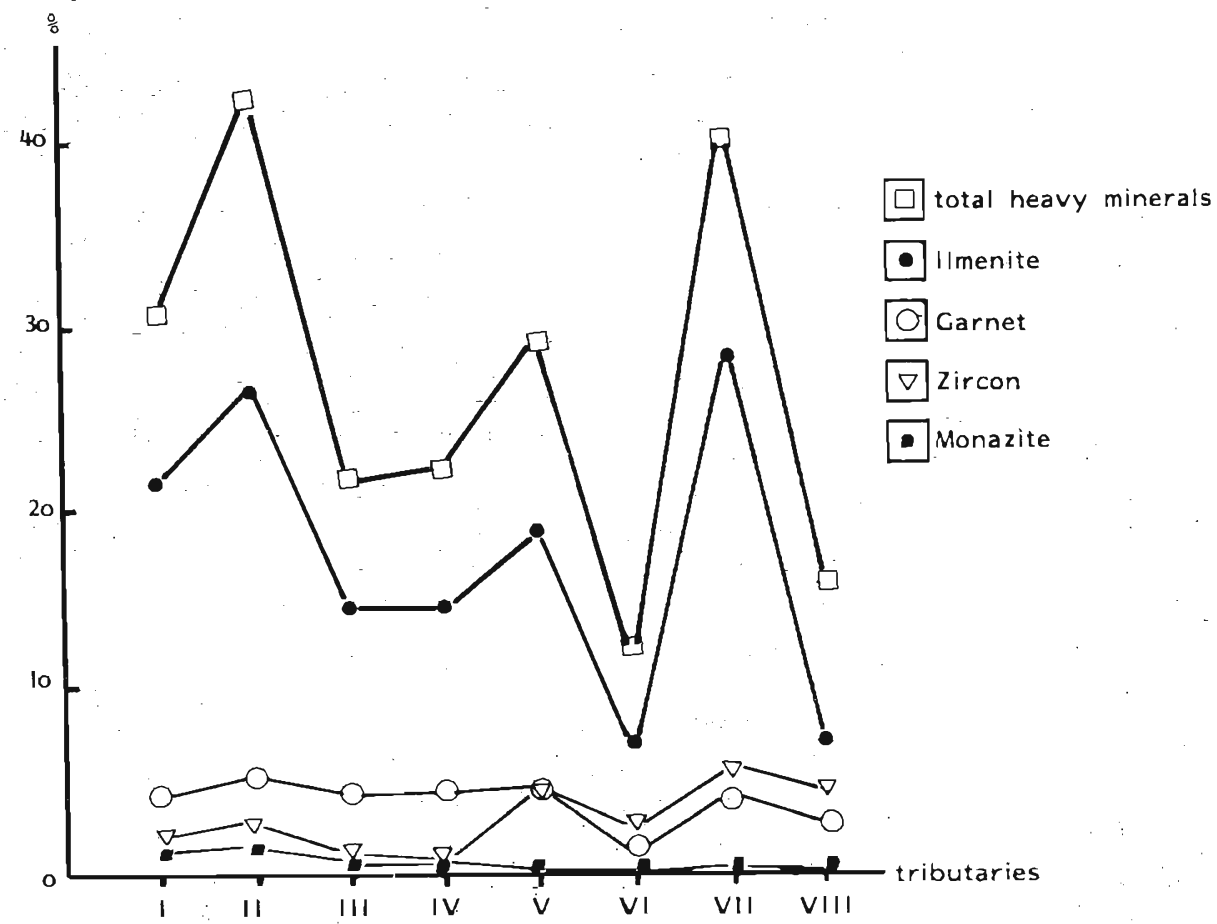

Figure 5 - Distribution of heavy minerals along the tributaries studied.

the typical alluvial monazite was used by the Imperial Institute of London ${ }^{9}$ to show that alluvial monazite was derived mainly from granulite instead of pegmatite. Dunstan $n^{7}$ showed that the schists, gneisses, granulites, acid charnockites and granitic rocks in the Southwestern and Central parts of Sri Lanka were the source of ilmeniterich concentrates containing small amounts of monazite and variable quantities of zircon and rutile. Cooray ${ }^{3}$ in his study of the geology of the Alutgama region found that monazite was introduced into the host rocks during widespread granitization that affected the area in the later stages of its plutonic history.

A study of nearly 20 thin sections of rocks from the area investigated showed that the gneisses and the granulites in particular, contained the heavy minerals observed in the alluvium. It is of interest to note that sillimanite was also found in the area studied could also be rich in heavy minerals. Coates ${ }^{1}$ considered this source to have supplied much of the monazite to the streams and beaches of Sri Lanka. One advantage of identifying a source terrain and working from it toward the placer deposit is that the same source terrain may contribute to several types of residual and 
placer deposits. ${ }^{8}$ Indeed, the high grade metamorphic rocks of the southwestern and central parts of Sri Lanka could well be the source rocks for a variety of placer deposits including the gem and gold bearing gravels. ${ }^{13}$ Some minerals of gem quality such as zircons, like monazite are considered to be invariable associates of gold and this association is common in Sri Lanka.

The genesis of the thorium-rich monazite sediments in Sri Lanka could best be discussed in the light of some recent views in the geologic evolution of Sri Lanka.

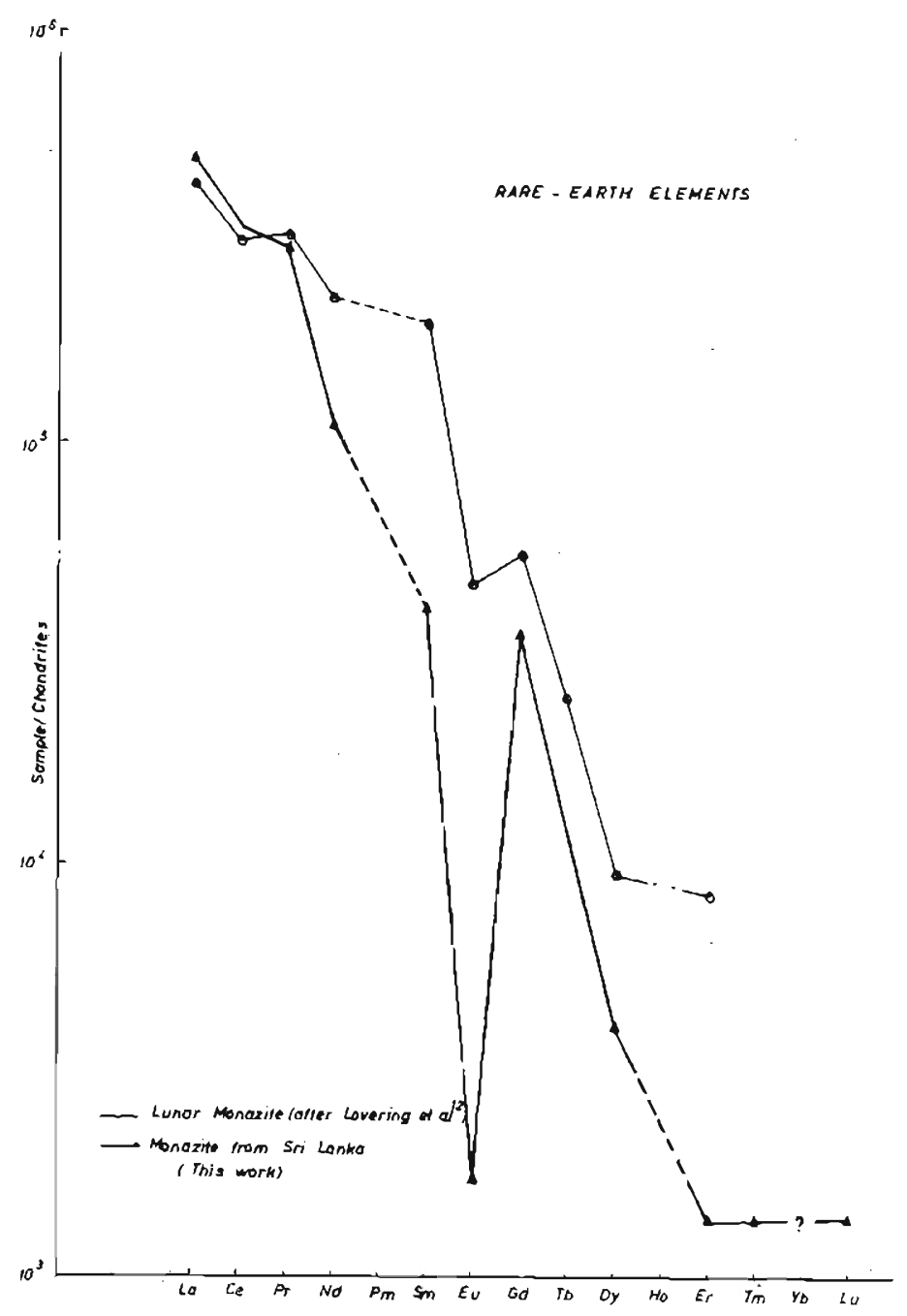

Fing 6: Chondrite normalized rare-earth elements of the monazite samples. 


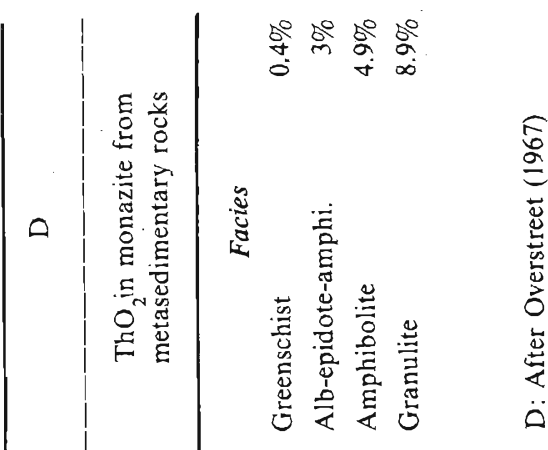

se so so

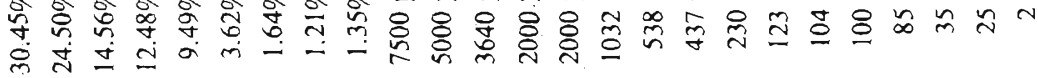

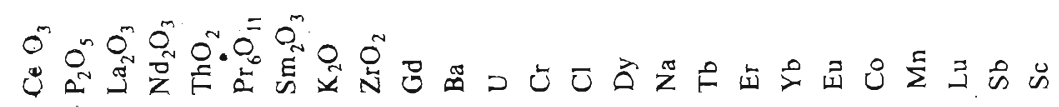

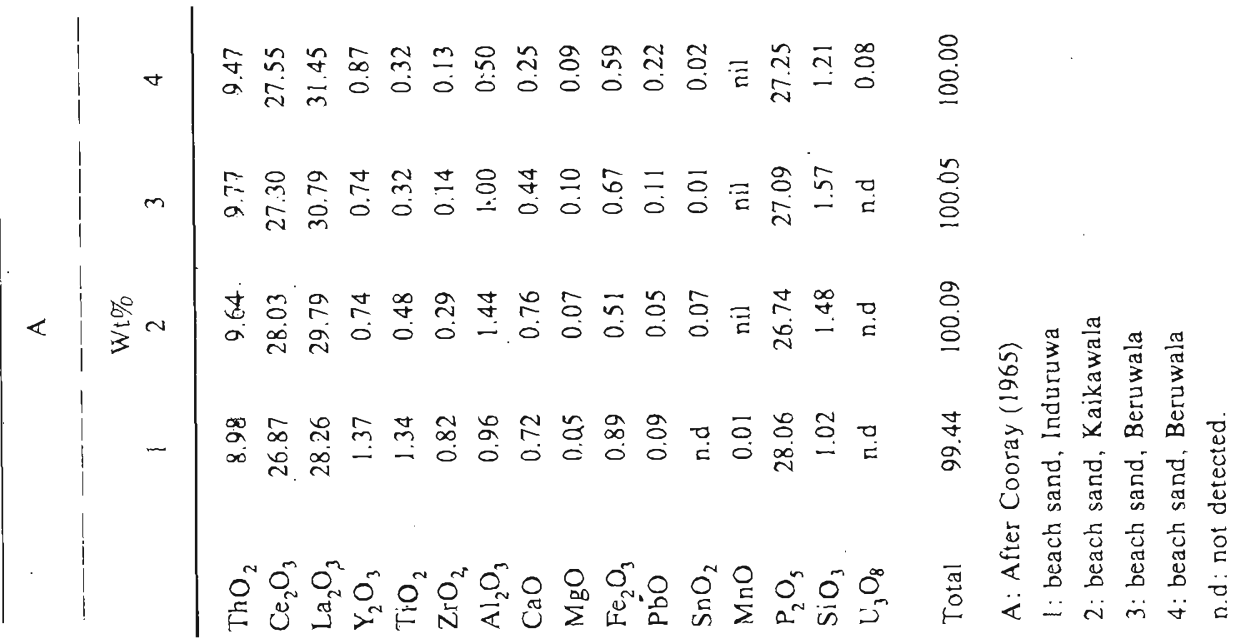


The central Highland Group is considered to be a former oceanic basin flanked by the castern and western parts of the Vijayan Complex (Figure 1), representing two Precambrian microplates which were closing up at varying rates. ${ }^{14}$ The oceanic basin was continuously filled with sediments of the sandstone-shale-limestone sequence. An increase in the rate of subduction caused the metamorphism of the sediments in the part of the basin lying closer to the trench at the eastern part. This was followed by the formation of granulite facies metamorphic rocks in the basin and the further convergence of the microplates deformed the basin producing tight folds, particularly in the Southwest Group where monazite bearing rocks occur. The deformed and metamorphosed oceanic crust penetrated parts of the metasedimentary cover producing different facies of the Southwest Group. This was accompanied by the emplacement of magmatic fluids produced by the basement remobilization associated with collision:

Overstreet ${ }^{15}$ outlined many features of monazite in schists and gneisses that show that it is of metamorphic origin. These features as given below are of particular significance in the genesis of monazite in the metamorphic terrain of Sri Lanka.

(a) Direct relation between amount of monazite in metamorphic rock and grain size of original sediment.

(b) Inverse relation between the range in grain size of particles of monazite in paraschists and paragneisses and the possible size range in the original sedimentary rock.

(c) Correlation between physical properties of monazite and metamorphic grade of host rock.

(d) Inclusions in monazite identical with metamorphic minerals in host rock.

(e) An inverse relation between monazite, allanite and other thorium bearing minerals in metamorphic rocks and a direct relation between the amount of thorium in monazite and the grade of regional metamorphism.

In the area studied and in the rocks of the Southwest Group of Sri Lanka in general, monazite occurs primarily as an accessory mineral in a variety of gneissic and granitoid rocks associated with migmatites: Cooray ${ }^{3}$ and Rupasinghe ${ }^{16}$ observed the occurrence of monazite in pegmatites and in migmatized charnockites. In the light of the above mentioned facts it seems probable that monazite was introduced into the host rocks during the intense magmatic activity associated with the metamorphism of the aluminous sediments under granulite facies conditions. These conditions proved very favourable for the genesis of minerals of gem quality such as garnet, sillimanite, andalusite, cordierite, zircon, corundum, etc. It is of interest to note that monazite of gem quality had also been found in Sri Lanka: ${ }^{10}$ 
The thorium content of Sri.Lanka monazite is very high and is exemplified by a comparison with the average $\mathrm{ThO}_{2}$ contents for different metamorphic facies (Table 1 ). As shown in Table 1 , apart from high thorium contents the rare-earth element concentrations are also extremely high. As shown in Figure 6, it is of interest to compare the rare-earth element contents of monazite from Apollo 11 basalt ${ }^{12} 11047,68$ and those of monazite from Sri Lanka (this work). A general similarity is seen with a more pronounced $\mathrm{Eu}$ anomaly in the Sri Lanka monazite samples. It is seen from the chondrite normalized REE fractionation pattern that the light REE's (La to Sm) are highly enriched relative to the heavy REE's ( $\mathrm{Gd}$ to $\mathrm{Lu}$ ). Lovering et al ${ }^{12}$ concluded that crystallization of monazite from late-stage liquids formed during crystallization of lunar igneous rocks could lead to these liquids to become increasingly depleted in the light REE's relative to the heavy REE's.

\section{Conclusions}

The foregoing study shows that thorium-rich monazite has been derived from a variety of gneisses and granitoid rocks in the Southwest and Highland Groups of Sri Lanka. The P-T conditions of metamorphism and the introduction of magmatic fluids during the deformation and metamorphism of the aluminous sediments resulted in the introduction of thorium-rich fluids and the formation of monazite. The extensive weathering under humid tropical conditions and subsequent transportation localized the heavy mineral-rich alluvial placers in Sri Lanka as exemplified by the area of this study. As shown by Goldsmith and Force ${ }^{8}$, geologic maps that show metamorphic zones and describe the kinds of rocks that make up a metamorphic terrain should serve as useful prospecting tools. The Southwest Group of Sri Lanka provides a good case in point and detailed mapping of the area would certainly prove worthwhile in the discovery of mineral deposits useful for Sri Lanka.

\section{Acknowledgements}

This work forms part of the Diploma thesis of M. S. Rapasinghe at the Free University of Berlin and was supervised by the co-authors. The author gratefully acknowledges the award of a research grant from the Otto Benecke Stiftunf, West Germany. He also wishes to thank the Geological Survey of Sri Lanka and the Department of Geology, University of Peradeniya Sri Lanka for their kind assisțance.

\section{References}

1. - COATES, J.S. (1935): Ceylon J: Sc XIX: 101-191.

2. CÓOMARASWAMY, A. K. (1906). Spolia Zeylanica 3: 198-199.

3. COORAY, P. G. (1965). Cëylon Geol: Surv. Dept. Memoir 3, 110 pp.

4. DAhanayake, K., LiYANAGE; A. N., \& RANASINGHe, A. P. (1980). Sed. Geol. 25: 105-115.

5. DISSANAYAKE, C. B.. \& NAW-ARATNE, S. W. (1981). Econ. Géol. 76: 733-738. 
6. DUNSTAN, W. R. (1905). Reports on the results of the mineral survey (of Ceylon) in 1903 - 4. Great Britain Colonial Office, Colonial reports Misc. 29, Ceylon. 3-42.

7. DUNSTAN, W. R. (1907). Reports on the results of the mineral survey (of Ceylon) in 1905-6. Great Britain Colonial Office, Colonial reports Misc. 42 Ceylon 3-34.

8. GOLDSMITH, R. \& FORCE, E. R. (1978). Mineralium Deposita 13: 329-343.

9. Imperial Institute of London. (1916). Imp. Inst. (London) Bull. 13 : 233-260.

10. JobBINS, E. A., TREShAM, A. E., \& YOUNG, B. R. (1977). J. Gemmology XV: 295-299.

11. KATZ, M. B. (1972), Econ. Geol. 67: 113-115.

12. LOVERING, J. F., WARK, D. A., GLEADOW, A. J. W. \& BRITTEN, R. (1974), Earth and Planetary Sci. lett. 21: $164-168$.

13. MUNASINGHE, T. \& DISSANAYAKE, C. B. (1981). Econ. Geol. 67: 113-115.

14. MUNASINGHE, T. \& DISSANAYAKE, C. B. (1982). J. Geol. Soc. India. 23: 369-380.

15. OVERSTREeT, W. S. (1967). U.S. Geol. Surv. Ptof. paper 530. 294 pp.

16. RUPASINGHE, M. S. (1980). Unpublished diploma thesis, Free University, Berlin, West Germany.

17. SILVA, K. K. M. W. (1976). Abst. 32nd Ann. Sess. Sri Lanka Ass Proc. Admt. S'ci. 